\title{
Dukungan Informasional Keluarga Berpengaruh dalam Pemberian ASI Eksklusif di Desa Timbulharjo Sewon Bantul
}

\author{
Nur Indah Rahmawati ${ }^{1}$ \\ ${ }^{1}$ Prodi D III Kebidanan Universitas Alma Ata Yogyakarta \\ Jalan Ringroad Barat Daya No 1 Tamantirto, Kasihan, Bantul, Yogyakarta \\ Email: vanda_bunga@yahoo.com
}

\begin{abstract}
Abstrak
Angka kematian bayi (AKB) di Indonesia menurut hasil survei demografi dan kesehatan (SDKI) mencapai AKB 32 per 1.000 kelahiran hidup di tahun 2012. Riset WHO menyebutkan bahwa 88\% kematian balita terkait dengan malnutrisi yang sering kali terkait dengan asupan ASI. Keluarga merupakan orang terdekat yang dapat membantu ibu dalam memberikan ASI eksklusif. Untuk itu dukungan keluarga sangat penting dalam keberhasilan pemberian ASl eksklusif. Tujuan penelitian untuk mengetahui hubungan dukungan informasional dalam keluarga dengan pemberian ASI eksklusif di desa Timbulharjo, Sewon, bantul. Penelitian ini adalah penelitian observasional analitik yang menggunakan pendekatan cross sectional. Penelitian ini menggunakan 76 responden yang memiliki bayi berusia 6-24 bulan yang mengikuti posyandu di desa Timbulharjo pada bulan April-Mei dengan teknik purposive sampling. Instrument yang digunakan dalam penelitian ini adalah kuesioner. Data yang di peroleh selanjutnya di analisis dengan menggunakan tabel distribusi frekuensi, chi-square dalam bentuk persentase dan odd ratio (OR). Hasil penelitian ini menunjukkan bahwa terdapat hubungan yang signifikan antara dukungan informasional dalam keluarga keluarga dengan pemberian ASI eksklusif dengan nilai korelasi chi-square $p=0,000$ dan nilai $O R=16$, ibu yang mendapatkan dukungan informasional tidak baik berpeluang 16 kali lebih banyak untuk tidak memberikasn ASI eksklusif pada bayinya. Kesimpulan terdapat hubungan yang signifikan antara dukungan emosional dalam keluarga dengan pemberian ASI eksklusif di Desa Timbulharjo, Sewon, Bantul.
\end{abstract}

Kata Kunci: ASI eksklusif, dukungan informasional dalam keluarga

\section{Informational Support in Family Influential of Exclusive Breastfeeding in Timbulharjo Village, Sewon, Bantul Yogyakarta}

\begin{abstract}
Infant Mortality Rate (IMR) in Indonesia according to the Demographic and Health Survey (IDHS) reached IMR was 32 per 1.000 live births in 2012. Research WHO states that $88 \%$ of child mortality linked to malnutrition, which is often associated with the intake of milk. Family is the closest person who can help the mother to give exclusive breastfeeding. For that family support is very important in the success of exclusive breastfeeding. The aim of research to determine the relationship of the family with the informational support exclusive breastfeeding in the village Timbulharjo, Sewon, Bantul. This study was observational analytic cross sectional approach. This study uses the 76 respondents who had infants aged 6-24 months that follow posyandu in Timbulharjo village in April-May with a purposive sampling techniques. The instrument used in this study was a questionnaire. Data were obtained subsequently analyzed using frequency distribution table, chi square as percentages and odds ratios (OR). The results of this study indicate that there is a significant relationship between the informational support to the families with exclusive breastfeeding correlation value chi square $p=0.000$ mothers who get no good informational support 16 times more likely to not memberikasn exclusive breastfeeding her baby. Conclusion There is a significant relationship between emotional support in the family with exclusive breastfeeding in the village Timbulharjo, Sewon, Bantul.
\end{abstract}

Keywords: exclusive breastfeeding, informational suport in family

Info Artikel:

Artikel dikirim pada 9 Juni 2016

Artikel diterima pada 20 Juni 2016

DOI : http://dx.doi.org/10.21927/jnki.2016.4(2).75-78 


\section{PENDAHULUAN}

Menurut Manuaba, salah satu upaya untuk peningkatan sumber daya manusia antara lain dengan jalan memberi air susu ibu (ASI) sedini mungkin (1). World Health Organization (WHO) menjelaskan bahwa ASI adalah makanan ideal untuk pertumbuhan dan perkembangan bayi (2). ASI merupakan makanan pertama, utama, dan terbaik bagi bayi yang bersifat alamiah.

Angka kematian bayi (AKB) di Indonesia menurut hasil Survei Demografi dan Kesehatan Indonesia (SDKI) mencapai AKB 32 per 1.000 kelahiran hidup ditahun 2012 kurang menggembirakan dibandingkan target Renstra Kemenkes yang ingin dicapai yaitu 24 per 1.000 kelahiran hidup juga target MDGs sebesar 23 per 1.000 kelahiran hidup ditahun 2015.

Angka kematian bayi (AKB) di D.I. Yogyakarta menurut hasil Survei Demografi dan Kesehatan (SDKI) tahun 2012 menunjukkan bahwa angka kematian bayi di DIY mempunyai angka yang relatif lebih tinggi, yaitu sebesar 25 per 1.000 kelahiran hidup (taget MDG's sebesar 23 per 1.000 kelahiran hidup pada tahun 2015). Data Profil Kesehatan Indonesia Tahun 2013 menunjukan bahwa persentase pemberian ASI eksklusif pada bayi 0-6 bulan di Indonesia sebesar $61,5 \%$.

Tahun 2008 cakupan ASI eksklusif di Provinsi DIY baru mencapai 39,9\%, menurun pada tahun 2009 yaitu sebesar $34,56 \%$. Tahun 2010 , cakupan ASI Eksklusif meningkat mencapai 40,57\% (target 80\%). Sedangkan pada tahun 2011, cakupan ASI Eksklusif kembali menunjukkan peningkatan menjadi $49,5 \%$. Lebih rinci, cakupan ASI eksklusif di Kabupaten Sleman sudah mencapai $\geq 60 \%$, di Gunung Kidul masih 20-39\%, sedangkan di Kabupaten/Kota Bantul masih berkisar $42,34 \%$ (3).

Caplan dalam Friedman menjelaskan bahwa keluarga memiliki fungsi dukungan yaitu dukungan informasional, dukungan penilaian, dukungan instrumental dan dukungan emosional (4).

Menurut Sudiharto dukungan keluarga mempunyai hubungan dengan suksesnya pemberian ASI eksklusif kepada bayi (5). Dukungan informasional adalah keluarga berfungsi sebagai sebuah keluarga diseminator atau penyebar informasi tentang semua informasi yang ada dalam kehidupan. Keluarga berfungsi sebagai pencari informasi yang berhubungan dengan masalah menyusui dari tenaga kesehatan, dan melakukan konsultasi, serta mencari informasi dari media cetak maupun sumber lain yang mendukung. Contohnya keluarga mencari informasi dari luar seperti Buku bacaan, majalah. Tujuan penelitian untuk mengetahui hubungan dukungan informasional dalam keluarga dengan pemberian ASI eksklusif di desa Timbulharjo, Sewon, Bantul.

\section{BAHAN DAN METODE}

Jenis penelitian ini adalah observasional analitik dengan rancangan cross sectional. Populasi pada penelitian ini meliputi seluruh ibu yang memiliki bayi beruisia 6-24 bulan yang berjumlah 320 orang dan penelitian dilakukan pada bulan April-Mei di desa Timbulharjo, Sewon, Bantul, Yogyakarta.

Teknik pengambilan sampel menggunakan purposive sampling, dimana banyaknya sampel di hitung dengan rumus Slovin. Sampel kemudian dipadukan dengan kriteria inklusi: Ibu yang menyusui, lbu yang bersedia menjadi responden, lbu yang datang keposyandu pada saat penelitian, dan kriteria eksklusi: Ibu yang tidak hadir di posyandu pada saat melakukan penelitian, Ibu yang pindah domisili.

Variabel bebas (independen) yaitu dukungan keluarga dan variabel terikat (dependen) yaitu pemberian ASI eksklusif. Instrument pada penelitian ini menggunakan kuesioner yang diadopsi dari penelitian Yuniar Dwi Irmawati pada tahun 2011 yang telah di uji validitas dan reabilitas (6). Analisis data pada penelitian ini menggunakan analisa univariat yang berguna untuk mengetahui gambaran distribusi frekuensi masing-masing variabel dan analisis bivariat yang berguna untuk mengetahui hubungan antara variabel independen dan variabel dependen. Uji yang digunakan adalah chi-square dan OR (odd ratio).

\section{HASIL DAN BAHASAN}

Desa Timbulharjo merupakan sebuah desa di Kecamatan Sewon, Bantul dimana sebagian besar warganya merupakan suku Jawa Desa timbulharjo ini dibawah naungan puskesmas sewon I. Desa Timbulharjo memiliki16 dusun yaitu Dadapan, Tembi, Gatak, Balong, Gabusan, Dagan, Sewon, Mriyan, kowen I, Kowen II, Dobalan, Sudimoro, Bibis, Ngasem, Kepek, dan Ngentak. Dari beberapa dusun ini memiliki 1 posyandu yang dibina oleh kader dan dan di bawah naungan Puskesmas Sewon I. 
Tabel 1. Tabel Karakteristik Ibu di Desa Timbulharjo, Sewon, Bantul

\begin{tabular}{lcc}
\hline \multicolumn{1}{c}{ Karaktristik } & $\mathbf{f}$ & $\%$ \\
\hline Umur & & \\
$\quad<25$ tahun & 22 & 28,9 \\
$25-35$ tahun & 37 & 48,7 \\
$\quad>35$ tahun & 17 & 22,4 \\
Pendidikan & & \\
$\quad$ Tidak tamat SD & 1 & 1,3 \\
SD & 6 & 7,9 \\
SMP & 22 & 28,9 \\
SMA & 34 & 44,7 \\
Perguruan Tinggi & 13 & 17,1 \\
Perkerjaan & & \\
IRT & 55 & 72,4 \\
Swasta & 9 & 11,8 \\
Buruh dan Karyawan & 8 & 10,5 \\
Wiraswasta & 2 & 2,6 \\
PNS & 2 & 2,6 \\
Jumlah & 76 & 100 \\
\hline
\end{tabular}

Berdasarkan Tabel 1 hasil penelitian umur, pendidikan dan pekerjaan dapat disimpulkan bahwa usia ibu yang menyusui masih di dominasi usia reproduktif yaitu usia 25-35 tahun dengan jumlah 37 dari 76 orang $(48,7 \%)$, sedangkan dari pendidikan mayoritas ibu berpendidikan SMA yaitu 34 dari 76 orang $(44,7 \%)$ dan terakhir dari ibu yang bekerja yaitu IRT dengan frekuensi 55 dari 76 orang $(72,4 \%)$.

\section{Dukungan}

Distribusi responden berdasarkan variabel dukungan instrumental di Desa Timbulharjo, Sewon, Bantul disajikan dalam Tabel 2.

Tabel 2. Distribusi Responden Berdasarkan Variabel Dukungan di Desa Timbulharjo, Sewon, Bantul

\begin{tabular}{lcc}
\hline Dukungan Instrumental & $\mathbf{n}$ & $\%$ \\
\hline Baik & 22 & 26,2 \\
Tidak Baik & 54 & 64,3 \\
Total & 76 & 100 \\
\hline
\end{tabular}

Dukungan informasional di dapatkan hasil bahwa sebagian besar ibu mendapatkan dukungan informasional baik yaitu 42 orang $(55,3 \%)$.

\section{Pemberian ASI Ekslusif}

Distribusi pemberian ASI eksklusif dan tidak eksklusif di Desa Timbulharjo, Sewon, Bantul disajikan dalam Tabel 3.

Tabel 3. Distribusi Pemberan ASI di Desa Timbulharjo, Sewon, Bantul

\begin{tabular}{lcc}
\hline Pemberian ASI & $\mathbf{n}$ & \% \\
\hline Eksklusif & 23 & 30,3 \\
Tidak Eksklusif & 53 & 69,7 \\
Total & 76 & 100 \\
\hline
\end{tabular}

Hasil penelitian menunjukkan bahwa sebagian besar ibu tidak memberikan ASI secara eksklusif pada bayinya yaitu sebanyak 53 orang $(69,7 \%)$.

\section{Hubungan Dukungan dengan Pemberian ASI Ekslusif}

Hasil analisis hubungan antara dukungan informasional dengan pemberian ASI eksklusif di Desa Timbulharjo, Sewon, Bantul disajikan dalam Tabel 4.

Hasil penelitian menunjukkan bahwa ada hubungan antara dukungan keluarga yaitu dukungan informasional dengan pemberian ASI eksklusif di Desa Timbulharjo, Sewon, Bantul.

Menurut Indiarti ASI eksklusif merupakan pemberian ASI pada bayi selama enam bulan tanpa makanan tambahan lain seperti susu formula, jeruk, madu, air the dan air putih serta tambahan makanan padat seperti pisang, bubur susu, biskuit, bubur nasi dan nasi tim (7).

Hasil tabulasi silang pada penelitian ini menunjukkan bahwa sebagian besar ibu mendapatkan dukungan informasional tidak baik

Tabel 4. Hubungan Dukungan dengan Pemberian ASI Eksklusif di Desa Timbulharjo, Sewon, Bantul

\begin{tabular}{|c|c|c|c|c|c|c|c|c|c|}
\hline \multirow{3}{*}{$\begin{array}{l}\text { Dukungan } \\
\text { Informasional }\end{array}$} & \multicolumn{4}{|c|}{ Pemberian ASI } & \multirow{2}{*}{\multicolumn{2}{|c|}{ Total }} & \multirow{3}{*}{$X^{2}$ hitung } & \multirow{3}{*}{$p$-value } & \multirow{3}{*}{ OR } \\
\hline & \multicolumn{2}{|c|}{ Eksklusif } & \multicolumn{2}{|c|}{ Tidak Eksklusif } & & & & & \\
\hline & $\mathbf{n}$ & $\%$ & $\mathbf{n}$ & $\%$ & $\mathbf{n}$ & $\%$ & & & \\
\hline $\begin{array}{l}\text { Baik } \\
\text { Tidak Baik }\end{array}$ & $\begin{array}{c}21 \\
2\end{array}$ & $\begin{array}{c}27,6 \\
2,6\end{array}$ & $\begin{array}{l}21 \\
32\end{array}$ & $\begin{array}{l}27,6 \\
42,1\end{array}$ & $\begin{array}{l}42 \\
34\end{array}$ & $\begin{array}{l}55,3 \\
44,7\end{array}$ & \multirow[t]{2}{*}{17,329} & \multirow[t]{2}{*}{0,000} & \multirow[t]{2}{*}{16,00} \\
\hline Jumlah & 23 & 30,2 & 53 & 69,8 & 76 & 100 & & & \\
\hline
\end{tabular}


dan tidak memberikan ASI eksklusif yaitu sebanyak 32 orang (32\%). Hasil nilai OR adalah sebesar 16,00. Hal ini berarti bahwa jika ibu tidak mendapatkan dukungan informasional dengan baik maka akan berpeluang 16,00 kali lebih banyak untuk tidak memberikan ASI secara eksklusif pada bayinya. Dukungan informasional adalah dukungan yang diberikan kepada seseorang dengan memberikan informasi, nasehat, saran dan petunjuk. Hasil tabulasi silang menunjukkan bahwa sebagian besar ibu yang mendapatkan dukungan informasional tidak baik dan tidak memberikan ASI secara eksklusif yaitu 32 orang $(42,1 \%)$. Nilai OR juga menunjukkan bahwa ibu yang mendapatkan dukungan informasional tidak baik berpeluang 16 kali lebih banyak untuk tidak memberikan ASI eksklusif pada bayinya. Hasil uji statistik menunjukkan bahwa terdapat hubungan signifikan dukungan informasional dengan pemberian ASI eksklusif dengan nilai $p$-value $=0,000$, artinya terdapat hubungan yang signifikan antara dukungan informasional dengan pemberian ASI ekslusif.

Hasil penelitian ini sejalan dengan penelitian Wicitra, yang menyatakan terdapat hubungan signifikan dukungan informasional keluarga terhadap pemberian ASI eksklusif $(p=0,031)$, dan $76,2 \%$ ibu yang tidak mendapatkan dukungan informasional tentang pemberian ASI mempunyai tindakan pemberian ASI yang tidak eksklusif (8). Senada dengan penelitian Fauzie, di ketahui salah satu yang paling penting diperhatikan dalam pemberian ASI secara eksklusif adalah pemberian informasi tentang ASI dan manfaat ASI khususnya oleh petugas kesehatan (9).

\section{SIMPULAN DAN SARAN}

Dukungan informasional pada ibu sebagian besar baik dan sebagian besar ibu memberikan ASI eksklusif dan ibu yang mendapatkan dukungan informasional baik berpeluang 16 kali untuk memberikan ASI eksklusif. Ada hubungan dukungan informasional dengan pemberian ASI eksklusif.

Kepada anggota keluarga khususnya suami penting memotivasi dan mendukung ibu dengan meningkatkan upaya-upaya yang mengarah pada pendekatan untuk memberikan ASI secara ekslusif bagi bayinya. Diharapkan kepada petugas kesehatan terutama bidan yang bertugas di daerah tersebut agar lebih kreatif dalam mengumpulkan warga untuk menyampaikan penyuluhan pendidikan dan mempromosikan ASI eksklusif serta informasiinformasi yang berhubungan dengan pemberian ASI ekslusif kepada seluruh anggota keluarga dengan di bantu oleh kader setempat. Diharapkan bagi peneliti selanjutnya dapat menggunakan metode lain dalam melakukan penelitian tentang dukungan keluarga dengan pemberian ASI eksklusif.

\section{RUJUKAN}

1. Manuaba. Ilmu Kebidanan, Penyakit Kandungan dan KB Untuk Pendidikan Bidan. Jakarta: EGC; 2006.

2. World Health Organization United Nations Children's Fund. Global strategy for infant and young child feeding. Geneva, Switzerland; 2003.

3. Dinkes DIY. Profil Kesehatan Propinsi DIY Tahun 2012. Yogyakarta; 2012.

4. Friedman MM. Keperawatan Keluarga Teori dan Praktik. Jakarta: EGC; 2013.

5. Sudiharto. Asuhan Keperawatan Keluarga dengan Pendekatan Keperawatan Transkultural. Jakarta: EGC; 2007.

6. Dwi Y. Hubungan antara Dukunga Keluarga pada Ibu Menyusui dengan Pemberian ASI Eksklusif di BPS Umu Hani Kasongan Bantul 2011. Yogyakarta; 2011.

7. Indiarti MT. Buku Pintar Ibu Kreatif, ASI, Susu Formula dan Makanan Bayi. Yogyakarta: Khasanah IImu Terapan; 2010.

8. Wicitra A. Faktor Dukungan Suami dan Faktor Pengetahuan Ibu Mengenai ASI Hubungannya dengan Lama Pemberian ASI pada Ibu Pegawai Swasta di Beberapa Perusahaan di Jakarta. Jakarta; 2009.

9. Fauzie R, Suradi R, Rezeki SS, Hadinegoro. Pattern and influencing factors of breastfeeding of working mothers in several areas in Jakarta. Paediatr Indones. 2007;47(1):27-31. 